\title{
Effect of Cadmium Toxicity on Aquatic Macrophyte Pistia Stratiotes (L.)
}

\section{Rolli N.M ${ }^{1 *}$, Suvarna khandi SS1, Gadi SB², Mulagund GS $^{3}$ and Taranath TC $^{3}$}

${ }^{1} B L D E A$ 's Degree College Jamkhandi, Karnataka, India

${ }^{2}$ Dept of Botany JSS College Dharwad, Karnataka, India

${ }^{3}$ Department of Botany Karnataka University Dharwad, India

\begin{abstract}
The present study focuses on cadmium toxicity on morphology and selected biochemical parameters of Pistia. The laboratory experiments were conducted for the assessment of morphological index parameters (MIP), biochemical parameters and accumulation of cadmium in plants at its various concentrations $(0.1,0.5,1.0,1.5$ and $2.0 \mathrm{ppm})$ at the regular interval for 12 days exposure. Pistia showed visible symptoms like withering of roots, chlorosis and necrosis at higher concentration $(2.0 \mathrm{ppm})$, however, the plant showed normal growth at lower concentration $(0.1 \mathrm{ppm})$. The estimation of biochemical parameters (Total chlorophyll, Protein and Carbohydrate) of test plants showed a significant increase at lower concentration $(0.1 \mathrm{ppm})$ of cadmium. The biochemical parameters decrease with increase in exposure concentration and duration. The toxic effect of cadmium is directly proportional to its concentration and duration. The accumulation of cadmium by Pistia stratiotes was maximum at 4 days exposure duration and marginal at subsequent concentrations and exposure duration. With respect to biochemical parameters the concentrations are significant. However, metal accumulation is significant at concentrations and exposure duration.
\end{abstract}

Keywords: Accumulation; Biochemical parameters; Cadmium; Toxicity

\section{Introduction}

Heavy metal contamination in the water bodies is increasing at an alarming rate due to industrial and anthropogenic activities [1]. Heavy metals cannot be degraded and therefore, are persistent. Efforts are being made to develop technologies that use biological materials effectively in removing heavy metals from the environment. Plants possess the capacity to accumulate heavy metals. Higher plant species possess physiological traits that enable them to tolerance and hyper accumulate metals [2,3]. The metal tolerance of plants may be attributed to different enzymes, stress proteins and phytochelatins [4]. The accumulation of metals at higher concentrations causes retardation of growth, biochemical activities and also generation of - $\mathrm{SH}$ group containing enzymes [5].

The aim of this study was to determine Cd toxicity on morphological index parameters (MIP), contents of total chlorophyll, protein and carbohydrates in submerged aquatic macrophyte, Pistia stratiotes.

\section{Materials and Methods}

Pistia stratiotes, a free floating aquatic plant from unpolluted water bodies and maintained in cement pots ( $1 \mathrm{~m}$ diameter) under natural conditions at a temperature $28-30^{\circ} \mathrm{C}$. About $20 \mathrm{~g}$ of young healthy Pistia is acclimatized for two weeks in Arnon and Hoagland nutrient solution [6] maintaining $\mathrm{pH}$ between 7.1-7.4. The concentrations of $\mathrm{Cd}$ in the polluted waters are in the range of $0.1,0.5,1.0,1.5$ and $2.0 \mathrm{mg} / \mathrm{l}$ and tap water as a control. Morphological Index Parameters (MIP) viz; root length, leaf length and breadth were observed for 12 days at interval of 4 days. Photographs of Pistia treated with different concentrations of cadmium were taken by using Canon's Power Shot G2 digital camera. For the further study the plants were harvested at the end of 4, 8 and 12 days exposure and are thoroughly washed with distilled water and used for the estimation of total chlorophyll, protein and carbohydrate and also for morphological observations. Plants harvested after $48 \mathrm{hrs}$ were dried at $80^{\circ} \mathrm{C}$ for 2 days for metal extraction.

The fresh plant sample of one $\mathrm{g}$ is macerated in $100 \mathrm{ml}$ of $80 \%(\mathrm{v} / \mathrm{v})$ chilled acetone by using pestle and mortar. The extract was centrifuged and supernatant was used for the estimation of total chlorophyll by standard method [7] using $652 \mathrm{~nm}$ against the solvent ( $80 \%$ acetone as a blank). The protein was estimated by Lowry's method [8] using Bovine Serum Albumin (BSA) as a standard using $660 \mathrm{~nm}$ and carbohydrates by phenol sulphuric acid method [9] using glucose as standard at 490 $\mathrm{nm}$. Morphological characteristics with the help of photographs using Canons Power Shot $\mathrm{G}_{2}$-digital camera.

The estimation of metal $(\mathrm{Cd})$ in the test plant was carried out by using standard method [10]. The dried and powdered $1 \mathrm{~g}$ plant material was digested by using mixed acid digestion method in Gerhardt digestion unit. The digested samples were diluted with double distilled water and filtered through Whatman filter paper No-44. The estimation of Cd was done by AAS (GBC 932 Plus Australia) with air acetylene oxidizing flame and metal hollow cathode lamp at 217.00 $\mathrm{nm}$ wavelength. Working standards (SISCO-Chem-Bombay Lab) were used for the calibration of instrument.

\section{Statistical analysis}

Data are presented as mean values \pm SE from two independent experiments with three replicates each. Data were subjected to Twoway ANOVA to know significance between concentrations and between exposure duration for the accumulation of heavy metal (Cd). Further, Dunet's test is also applied for multiple comparisons between control and other concentrations. Two-way ANOVA test is also extended to know the significance between concentration and duration for biochemical parameters.

*Corresponding author: Dr. N.M. Rolli, Associate Professor, BLDEA's Degree College, Jamkhandi, 587301, Karnataka, India, Tel: 9448896839; Fax: (08353)220183; E-mail: drnmrolli@rediffail.com

Received November 29, 2013; Accepted December 23, 2013; Published December 27, 2013

Citation: Rolli NM, Suvarna khandi SS, Gadi SB, Mulagund GS, Taranath TC (2013) Effect of Cadmium Toxicity on Aquatic Macrophyte Pistia Stratiotes (L.). J Environ Anal Toxicol 4: 201. doi: 10.4172/2161-0525.1000201

Copyright: ( 2013 Rolli NM, et al. This is an open-access article distributed under the terms of the Creative Commons Attribution License, which permits unrestricted use, distribution, and reproduction in any medium, provided the original author and source are credited. 
Citation: Rolli NM, Suvarna khandi SS, Gadi SB, Mulagund GS, Taranath TC (2013) Effect of Cadmium Toxicity on Aquatic Macrophyte Pistia Stratiotes (L.). J Environ Anal Toxicol 4: 201. doi: 10.4172/2161-0525.1000201

Page 2 of 4

\section{Results and Discussions}

\section{Morphological toxicity}

Morph metric assay is one of the quantitative tools for the assessment of toxicants was measured by using Morphological Index Parameter (MIP). The rate of inhibition of growth in the root and leaf is directly proportional to the concentration of Cd. Two-way ANOVA test states that the concentrations are significantly toxic at 5\% level but duration is not significant. MCA test is also represent maximum deviation is at higher concentration compared to control (Table 1). The plant showed normal growth. Similar observation was made by Garg et al. [11] in Limnanthemum cristastum at $1 \mathrm{ppm}$ concentration of $\mathrm{Pb}$, $\mathrm{Zn}$ and $\mathrm{Cr}$. The higher concentration of $\mathrm{Cd}(0.5$ to $2.0 \mathrm{ppm})$ exhibited toxicity symptoms like chlorosis and leaf fall were observed, then brownish was occurred being more marked in old leaves especially at $2.0 \mathrm{ppm} \mathrm{Cd}$ concentration such adverse effect of $\mathrm{Pb}$ on the growth has been reported by Dogan and Saygideger [12] and Kopittke et al. [13]. Similar observations were made by Yongpisanphop et al. [14] in Salvinia natanus and Wolff et al. [15] in Salvinia auriculata.

\section{Biochemical toxicity}

Chlorophyll content is a parameter that is sensitive to heavy metal toxicity [16]. Cadmium at $0.1 \mathrm{mg} / \mathrm{lt}$ found to augment chlorophyll synthesis and directly proportional to the duration, the content increased by $0.79 \%, 1.04 \%$ and $1.30 \%$ at 4,8 and 12 days exposure compared to control pond. Similar observation has been reported by Singh et al. [2] in Hydrilla verticillata and Dhir and Srivastava [17] in Salvinia natanus at $10 \mathrm{mg} / \mathrm{lt}$ of $\mathrm{Cu}, \mathrm{Fe}, \mathrm{Zn}, \mathrm{Co}, \mathrm{Cr}$. The stimulations of chlorophyll synthesis may be due to phytochelatins (PCs) which plays role in detoxification [18]. However, the higher concentration of $\mathrm{Cd}$ found to inhibit the chlorophyll synthesis. The inhibition at $2.0 \mathrm{mg} / \mathrm{lt}$ Cd by $20.05 \%, 31.49 \%$ and $39.58 \%$ (significant at $\mathrm{P}>0.95$ ) at 4,8 and 12 days exposure respectively compared to control. Two-way ANOVA represents biochemical toxicity to the test plant, concentrations are significant at $\mathrm{P}>0.01$ level but duration is not significant. Two-way ANOVA represents, cadmium toxicity is at $\mathrm{P}>0.01$ level significant towards but duration is not significant (Figure 1A).

Higher metal concentration, $\mathrm{Pb} 20 \mathrm{mg} / \mathrm{lt}$ and $5.0 \mathrm{mg} / \mathrm{lt} \mathrm{Cd}$ showed decrease in total chlorophyll [2]. The decline in chlorophyll content in plants exposed to Cd due to i) inhibition of important enzymes associated with chlorophyll biosynthesis ii) peroxidation of chloroplast membranes resulting from heavy metal induced oxidative stress and iii) formation of metal substituted chlorophyll [19].

Carbohydrate content of Pistia at $0.1 \mathrm{ppm}$ increased to the extent of $8.82 \%, 11.42 \%$ and $13.15 \%$ respectively at 4,8 and 12 days exposure compared to control. It is believed that $\mathrm{Cd}$ and $\mathrm{Pb}$ are inducers for phytochelatin synthesis and definite role of detoxification of $\mathrm{Cd}$ and $\mathrm{Pb}$ and hence increase in the carbohydrate content at lower $(0.1 \mathrm{ppm})$ concentration [20]. However, the high concentration of $\mathrm{Cd}$ found to inhibit carbohydrate. The inhibition at $2 \mathrm{mg} / \mathrm{lt}$ of Cd by $47.05 \%$,
(A) Total Chlorophyll
(B) Carbohydrate (C) Protein

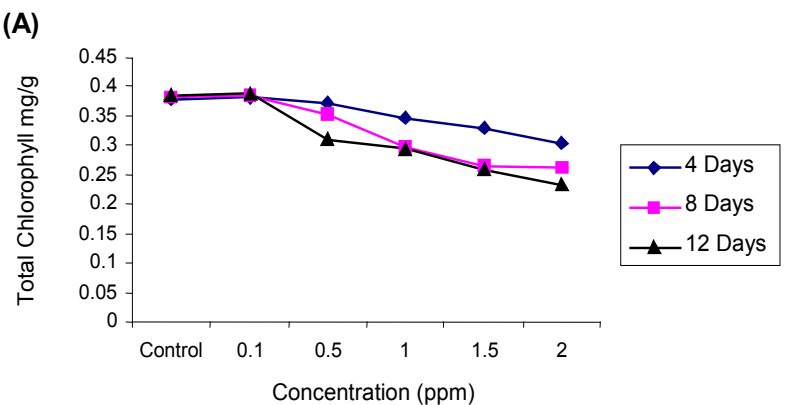

(B)

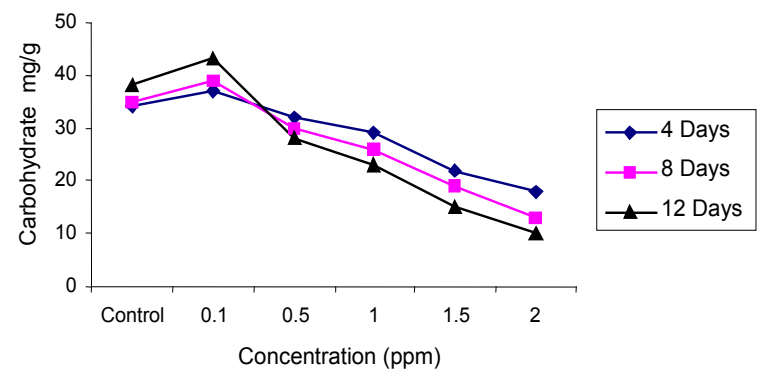

(C)

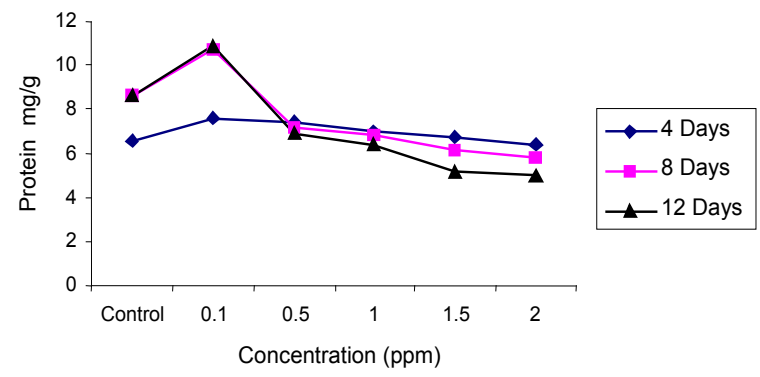

Figure 1: Biochemical effects of Cadmium on Pistia. (A) Total Chlorophyll (B) Carbohydrate (C) Protein

\begin{tabular}{|c|c|c|c|c|c|c|c|c|c|}
\hline \multirow[t]{4}{*}{ Conc (ppm) } & \multicolumn{9}{|c|}{ Exposure Duration (in days) } \\
\hline & 4 & 8 & 12 & 4 & & 8 & & 12 & \\
\hline & \multirow{2}{*}{\multicolumn{3}{|c|}{ Root length }} & \multicolumn{6}{|l|}{ Leaf size } \\
\hline & & & & Length & Breadth & Length & Breadth & Length & Breadth \\
\hline Control & $6.1 \pm 0.04$ & $6.16 \pm 0.07$ & $6.3 \pm 0.12$ & $1.4 \pm 0.04$ & $1.33 \pm 0.02$ & $1.46 \pm 0.02$ & $1.36 \pm 0.02$ & $1.47 \pm 0.02$ & $1.37 \pm 0.04$ \\
\hline 0.1 & $7.0 \pm 0.072$ & $7.13 \pm 0.03$ & $7.33 \pm 0.02$ & $1.66 \pm 0.02$ & $1.533 \pm 0.02$ & $1.66 \pm 0.02$ & $1.53 \pm 0.04$ & $1.73 \pm 0.02$ & $1.66 \pm 0.02$ \\
\hline 0.5 & $6.36 \pm 0.07$ & $6.26 \pm 0.07$ & $6.1 \pm 0.047$ & $1.5 \pm 0.047$ & $1.333 \pm 0.027$ & $1.5 \pm 0.047$ & $1.33 \pm 0.02$ & $1.33 \pm 0.02$ & $1.11 \pm 0.02$ \\
\hline 1.0 & $4.76 \pm 0.04$ & $4.6 \pm 0.08$ & $4.29 \pm 0.04$ & $1.4 \pm 0.047$ & $1.333 \pm 0.027$ & $1.4 \pm 0.047$ & $1.33 \pm 0.02$ & $1.3 \pm 0.02$ & $1.21 \pm 0.02$ \\
\hline 1.5 & $4.53 \pm 0.07$ & $4.46 \pm 0.15$ & $3.24 \pm 0.04$ & $1.33 \pm 0.02$ & $1.066 \pm 0.720$ & $1.2 \pm 0.00$ & $1.06 \pm 0.07$ & $1.0 \pm 0.00$ & $1.1 \pm 0.027$ \\
\hline 2.0 & $4.0 \pm 0.355$ & $3.16 \pm 0.02$ & $2.9 \pm 0.35$ & $1.2 \pm 0.047$ & $0.833 \pm 0.027$ & $1.0 \pm 0.00$ & $0.81 \pm 0.07$ & $0.7 \pm 0.00$ & $0.6 \pm 0.072$ \\
\hline
\end{tabular}

Values are expressed in $\mathrm{cms}$

Mean-values \pm standard Error

Table 1: Morphological response of Pistia stratiotes to Cadmium. 


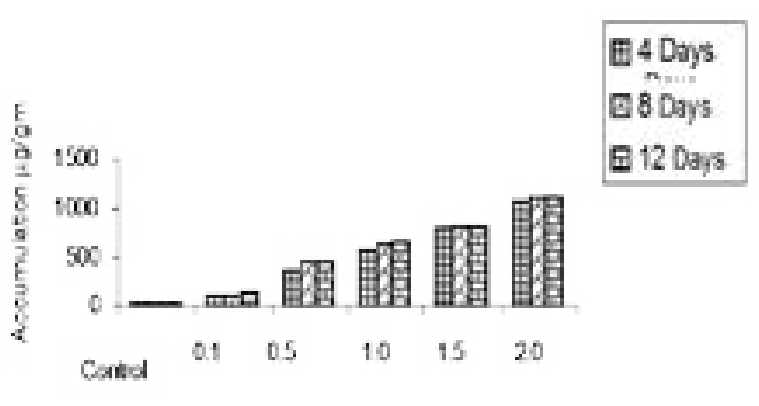

Conourtesen (pom)

Figure 2: Accumulation profile of Cadmium by Pistia.

$62.85 \%$ and $74.35 \%$ (significant at $\mathrm{P}>0.05$ ) at 4,8 and 12 days exposure respectively compared to control. Two way statistical ANOVA represents biochemical toxicity to the test plant concentrations are significant at $\mathrm{P}$ $>0.01$ level but duration is not at significant level (Figure 1B).

Many studies show that the protein content of many aquatic macrophytes was increased by accumulation of $\mathrm{Pb}$ at lower toxicity concentration [21]. The protein content increase marginally at $0.1 \mathrm{ppm}$ at $2.22 \%, 8.33 \%$ and $12.24 \%$ respectively at 4,8 and 12 days exposure compared to control. The stimulation of protein synthesis at lower concentration of $\mathrm{Cd}(0.1 \mathrm{ppm})$ may be attributes to the synthesis of stress proteins. The phytochelatins (PC) and phytochelatin synthetase bind and regulate the $\mathrm{Cd}$ and sequester the toxicity in the plants and thus, shows metal tolerance $[18,22]$. The reduction in protein content was observed with progressive increase in Cd concentration. Protein content in Pistia decreased by $24.44 \%, 45.83 \%$ and $59.81 \%$ respectively at 4,8 and 12 days exposure at $2.0 \mathrm{ppm}$ concentration compared to control $(\mathrm{P}>0.01)$ (Figure $1 \mathrm{C})$. The $\mathrm{Cd}$ induces oxidative stress by generating reactive oxygen species (ROS). These disrupt cellular homeostasis, thus, enhances the production of ROS. These ROS reacts with proteins, lipids, nucleic acids causing membrane damage and enzyme inactivation [11,23]. The decrease in protein content of macrophyte may be due to the above reasons.

\section{Metal Accumulation}

Figure 2 shows the concentration of Cd accumulated in Pistia. There was increase in the accumulation may be due to availability of increased number of binding sites for the complexation of heavy metal ions leading to the increased absorption. In the test plant the accumulation of $\mathrm{Cd}$ is directly proportional to exposures and concentrations. The Pistia grown in experimental pond containing $0.1 \mathrm{ppm}$ accumulate 112.50 $\mu \mathrm{g} / \mathrm{gm}, 130.75 \mu \mathrm{g} / \mathrm{gm}$ and $133.75 \mu \mathrm{g} / \mathrm{gm}$ and accumulation at high concentration (2.0) was $1270.0 \mu \mathrm{g} / \mathrm{gm}, 1375.25 \mu \mathrm{g} / \mathrm{gm}$ and $1381.00 \mu \mathrm{g} /$ gm during 4,8 and 12 days exposures respectively. It was observed that the rate of accumulation is maximum at 4 days exposure irrespective of concentrations; however, at remaining durations it is marginal. Similar observations were made by Bendra et al. [24] in Cladophora glomerata at the concentration $0.1 \mathrm{M}$ solution Cd Initial increase in the accumulation may be due to the availability of increased number of binding sites for the complexation of heavy metal ions leading to the increased absorption, however, slow accumulation may be attributed to binding almost all ions to the plants and establishment of equilibrium status between adsorbate and adsorbent $[3,25]$.
Two way ANOVA represents concentration and exposure duration are significant at $\mathrm{P}<0.01$ and Dunet's test reveals the concentrations are significantly differ with control.

\section{Acknowledgement}

The authors are thankful to the Principal, BLDEA's Degree College Jamkhand (Karnataka) and also to the Chairman, PG Department Botany, Karnataka University, Dharwad for providing necessary facilities to carry out research work.

\section{References}

1. Meagher RB (2000) Phytoremediation of toxic elemental and organic pollutants. Curr Opin Plant Biol 3: 153-162.

2. Singh A, Kumar CS, Agarwal A (2011) Phytotoxicity of Cadmium and Lead in Hydrilla verticillata (L.F) Royle. Journal of Physiology 3: 01-04.

3. Sbihi K, Cherifi O, El gharmali A, Oudra B, Aziz F (2012) Accumulation and toxicological effects of cadmium, copper and zinc on the growth and photosynthesis of the fresh water diatom Planothidium lanceolatum (Brebisson) Lange-Bertalot: A laboratory study. J Mater Environ Sci 3: 497-506.

4. Van Asche F, Clijsters H (1990) Effects of metals on enzyme activity in plants Plant Cell Environ 13: 195-206.

5. Vestena S, Cambraia J, Ribeiro C, Oliveira JA, Oliva MA (2011) Cadmium induced Oxidative stress and antioxidative enzyme response in water hyacinth and Salvinia. Braz J Plant Physiol 23: 131-139.

6. Arnon DI, Hoagland DR (1940) Crop production in artificial culture solutions and in soil with special reference to factor influencing yields and absorption of inorganic nutrients. Soil Sci 50: 463-483.

7. Arnon DI (1949) Copper enzymes in isolated chloroplasts. polyphenoloxidase in beta vulgaris. Plant Physiol 24: 1-15.

8. Lowry OH, Rosebrough NJ, Farr AL, Randall RJ (1951) Protein measurement with the Folin phenol reagent. J Biol Chem 193: 265-275.

9. Dubois M, Gilles KA, Hamilton JK, Rebers PA, Smith F (1956) Colorimetric method for determination of sugars and related substances. Anal Chem 28: 350-356.

10. Allen SE, Grimshaw HM, Parkinson JA, Quarmby C (1974) Chemical analysis of ecological materials. Blackwell Scientific Publications, Oxford.

11. Garg P, Chandra P, Devi S (1994) Chromium (VI) induced morphologica changes in Limnanthemum cristatum Griseb: A possible bioindicator. Phytomorphology 44: 201-206.

12. Dogan M, Saygideger SD, Colak U (2009) Effect of lead toxicity on aquatic macrophyte Elodea canadensis Michx. Bull Environ Contam Toxicol 83: 249-254.

13. Kopittke PM, Asher CJ, Kopittke RA, Menzies NW (2007) Toxic effects of Pb2+ on growth of cowpea (Vigna unguiculata). Environ Pollut 150: 280-287.

14. Yongpisanphop J, Kruatrachue M, Pokethitiyook P (2005) Toxicity and accumulation of lead and chromium in Hydrocotyle umbellata. J Environ Biol 26: 79-89.

15. Wolff G, Pereira GC, Castro EM, Louzada J, Coelho FF (2012) The use of Salvinia auriculata as a bioindicator in aquatic ecosystems: biomass and structure dependent on the cadmium concentration. Braz J Biol 72: 71-77.

16. Gupta P, Chandra P (1996) Response of Cadmium to Ceratophyllum demersum L., a rootless submerged plant. Waste Manag 116: 335-337.

17. Dhir B, Srivastava S (2013) Heavy metal tolerance in metal hyperaccumulator plant, Salvinia natans. Bull Environ Contam Toxicol 90: 720-724.

18. Rolli NM, Suvarnakhandi SS, Mulgund GS, Ratageri RH, Taranath TC (2010) Biochemical responses and accumulation of cadmium in Spirodela polyrhiza. J Environ Biol 31: 529-532.

19. Patsikka E, Kairavuo M, Sersen F, Aro EM, Tyystjarvi E (2002) Excess copper predisposes photosystem II to photoinhibition in vivo by outcompeting iron and causing decrease in leaf chlorophyll. Plant Physiol 129: 1359-1367.

20. Bhattacharya M, Choudhary MA (1995) Heavy metal $(P b+2$ and $C d+2)$ stress induced damages in Vigna seedlings and possible involvement of phytochelatins like substances in mitigation of heavy metal stress. Ind J Exp Biol 33: 236-238.

21. Mohan BS, Hosetti BB (1997) Potential phytotoxicity of lead and cadmium to Lemna minor grown in sewage stabilization ponds. Environ Pollution 98: 233-238. 
Citation: Rolli NM, Suvarna khandi SS, Gadi SB, Mulagund GS, Taranath TC (2013) Effect of Cadmium Toxicity on Aquatic Macrophyte Pistia Stratiotes (L.). J Environ Anal Toxicol 4: 201. doi: 10.4172/2161-0525.1000201

Page 4 of 4

22. Steffens JC (1997) The heavy metal binding peptides of plants. Ann Rev Plant Physiol Plant mol Biol 41: 553-575.

23. Romero-Puertas MC, Corpas FJ, Rodriguez-Seranno M, Gornez M, Del Rio LA, et al. (2007) Differential expression regulation of antioxidative enzymes by cadmium in pea plants. J Plant Physiol 164: 1346-1357.
24. Mc Hardy BM, George JJ (1990) Bioaccumulation and toxicity of $\mathrm{Zn}$ in the green alga, Cladophora glomerata. Environ Pollut 66: 55-66.

25. Rai AK, Kumar S (1999) Removal of Cr (VI) by low cost dust adsorbents. Applied Microbiol Biotechnol 39: 661-667. 